\title{
PARTY AUTONOMY
}

\author{
Lord Cooke of Thorndon*
}

This is an augmented version of a paper delivered at the International Centre for Alternative Dispute Resolution, New Delhi, in December 1998.

It is a privilege to be here, and the fulfilment of a long-cherished ambition. For many years, and increasingly, I have admired the achievements of the Indian courts, particularly the Supreme Court of India. Like most people everywhere I have aspired to see the Taj Mahal and other beauties and historic places of this great nation. At last, through the kindness of this enlightened Centre, I have had the opportunity of experiencing something of these institutions and attractions at first hand. For this I am truly grateful.

Your Centre is virtually coeval with the Arbitration and Conciliation Act 1996 ("the Indian Act") of the Parliament of India. As its Preamble suggests, the Act is largely based on the UNCITRAL Model Law on International Commercial Arbitration, adopted by the United Nations Commission on International Trade Law in 1985. The Act received the assent of the President on 16 August 1996. Thus it can be said to have lagged marginally behind the corresponding modern English legislation, the Arbitration Act 1996 ("the English Act"), to which the Queen assented on 17 June 1996. From another point of view, however, the Indian Act may be seen to be in advance of the English Act. The latter is much less an adoption of the UNCITRAL Model Law. It preserves much more of the paraphernalia and complexity of the law relating to arbitration as it had evolved over the years in both jurisdictions, although it modernises some of this in form and was evidently increasingly influenced by the UNCITRAL Model Law as the work of the Parliamentary Advisory Committee on Arbitration Law progressed. ${ }^{1}$ For example the English Act in section 69 enables appeals to the court on points of law, subject to fairly strict criteria,

* Lord of Appeal, United Kingdom; Distinguished Visiting Fellow, Faculty of Law, Victoria University of Wellington.

1 Successive chairmen of this Committee have become Law Lords, namely Lord Mustill, Lord Steyn and Lord Saville. In 1989 under the chairmanship of Lord Justice Mustill, as he then was, the Committee recommended legislation in the nature of a codification of existing statutory and common law. The ultimate Bill owed much to the work of Lord Justice Saville, as he then was, who is regarded as its principal architect. It goes well beyond codification. 
whereas the Indian Act and the UNCITRAL Model Law make no such provision. But under the English Act the parties may exclude appeals by agreement, so both Acts attach high importance to the concept that has come to dominate arbitration law towards the end of the twentieth century: party autonomy.

In moving the second reading of the English Bill in the House of Lords on 18 January 1996, the Minister of State, Department of Trade and Industry, Lord Fraser of Carmyllie, said. ${ }^{2}$

The principle of party autonomy is central to the Bill. The parties who are in dispute are able to decide how the arbitration should be conducted. The flexibility and control which this freedom gives to the parties is of critical importance. Having said that, the freedom is not absolute. There are a small number of provisions which for reasons of public policy cannot be overridden.

Section 1 of the English Act lays down three principles in the light of which Part I is to be construed. The second of these is that "the parties should be free to agree how their disputes are resolved, subject only to such safeguards as are necessary in the public interest". While the Indian Act contains no corresponding express affirmation of principle, its tenor throughout is redolent of the same idea. Recourse to the court, where available, is envisaged primarily as an aid to the arbitral process, as an auxiliary mechanism. The court is a powerful ally rather than a controller or a jealous conservator of its own power. By sections 34 and 48 an award may be set aside by the court, or enforcement of a foreign award refused, only on very limited and obviously necessary grounds, such as invalidity of the arbitration agreement, excess of jurisdiction as to the scope of the arbitration, and conflict with the public policy of India. Error of law alone, however significant and however manifest on the face of the award, is not enough.

The contemporary "politically correct" approach is thus that parties are free and should be encouraged to submit their disputes to arbitration (or some other alternative dispute resolution procedure, but this paper has to be confined mainly to arbitration) and - what is inseverable - that a party who loses, or becomes dissatisfied in the event, is allowed next to no room for repentance if there has been a fair hearing. The autonomy is that of the parties acting together when they make their arbitration agreement. It is not of course that of a party later disenchanted. The new-found emphasis on party autonomy represents a far cry from the days when Scrutton LJ recoiled from the thought that an English arbitration could be conducted without the possibility of the court being entitled to exercise its statutory

2568 HL Deb 761. 
power to require the arbitrators to state a special case. ${ }^{3}$ In his famous analogy of Alsatia the Lord Justice in effect likened an area of arbitration immune from that power as a haunt of thieves. Since then the pressures of judicial workloads have led the courts to entertain towards arbitrators a sense of gratitude rather than rivalry, of respect rather than contempt. In the Indian superior courts alone, the background of many thousands of cases is a powerful incentive to the new philosophy.

So the Indian Institute, the ICADR, is vitally concerned with party autonomy, and the concept seems a suitable one for a little exploration in a paper for this conference. I propose to discuss it with particular reference to the ability of the parties and arbitrators to select as the substantive law governing their arbitration a system of principles not being part of any specific national system of law, or no more than equity and reasonableness in a wide and non-technical sense. But before doing so it is relevant to make some disclosure of antecedents.

In their practical philosophy of law lawyers are what their cases have made them. Personal background, upbringing and experiences of life outside the law naturally shape one's general outlook. In the professional work of a lawyer another major influence is exerted. Whether he or she is sitting as a judge or arbitrator, or operating as a conciliator or mediator, or practising as an advocate or a solicitor, cases in which there has been a previous involvement leave a legacy to be drawn upon consciously or otherwise. Having been in the law for half a century, half of it as a judge and the earlier part as a barrister and, rather more briefly, as an academic, I have inevitably played some part in numerous cases concerned in one way or another with arbitration. In retrospect three of them stand out as experiences which have strongly inclined me towards sympathy for party autonomy. I hope that each is sufficiently germane to the subject this morning to warrant brief mention.

\section{SOME FORMATIVE EXPERIENCES}

At the bar in 1969 I was engaged in a case called Wellington City v National Bank of New Zealand Properties Ltd. ${ }^{4}$ It concerned an arbitration to fix a ground rent under a perpetually-renewable lease. The right of renewal arose every 21 years, when a new rent was to be fixed by arbitration if not agreed. This was a test case and there was a strong arbitral tribunal chaired by a retired senior judge of the Supreme Court (now renamed the High Court). One of the other two members was a retired judge of the Arbitration Court,

3 Czarnikow v Roth, Schmidt \& Co [1922] 2 KB 478, 487-9. There is perhaps more to be said for the merits of this decision than is sometimes assumed. The clause purporting to exclude the case stated procedure was contained in trade association rules; it can be seen as the product of monopoly power rather than free bargaining. See further CBI NZ Ltd v Badger Chiyoda [1989] 2 NZLR 669, 678, 685, 691, 692, 697.

4 [1970] NZLR 660. 
an industrial court which settled wages and conditions of employment. The parties were agreed that the rent for the next 21 years was to be arrived at by applying an appropriate rate of interest to the unimproved value of the land. The issue reduced to what was that rate. The valuers called for the city (for whom I was counsel) contended for up to 8 per cent; the valuers called for the lessee urged 2 or 3 per cent. Ultimately the chairman and the other arbitrator just mentioned awarded 4 per cent. That was acceptable to the city, but not to the bank.

An application to the court was brought by the bank for remission of the award on the ground that on its face, for it was fully reasoned, it was erroneous in law. The alleged error of law lay in the rejection of a submission for the bank that the tenant was "entitled as of right to an accounting of the capital growth which the landlord enjoys", coupled with the acceptance of a proposition to the contrary that "it is matters that affect the lessee and the lessee alone that are important in arriving at what he is prepared to pay". What lay behind that rejection and acceptance was that during the 21 year term the value of the land was likely, at least nominally, to increase. In large measure the increase would be only nominal, representing inflation or the fall in the value of money. To some extent it would be real, reflecting the scarcity value of prime central land in a city expanding but physically confined. The argument for the lessee was that the lessor did nothing towards the increase in apparent value attributable to either cause, whereas the lessee at least looked after the land and put it to use. I was rather proud at having persuaded one of the lessee's valuers to accept in cross-examination that, carried to its logical conclusion, this argument meant that, instead of receiving a rent, the lessor should pay the lessee for the latter's services as caretaker. But I was overconfident. The Chief Justice of the day, who had not been in office very long, was so bold as to hold that the retired senior judge and his colleague had indeed erred in law.

Shortly after the delivery of the Chief Justice's decision, I happened to be in a queue for lunch, at the Law Society's cafeteria, immediately behind the retired senior judge. It soon became evident that he was trying to tell me something. He kept talking of the Court of Appeal and the extent of my practice there. As it happened this hint of his hope was unnecessary, for I had already advised the city to appeal. The appeal duly succeeded, the judges taking the view that the "as of right" proposition for the lessee was unsustainable in law and that the proposition in the reasons for the award about what was important for the lessee was not a proposition of law at all, but a commonsense observation of fact.

The lesson which I drew from that case was that the then venerable but fully extant common law jurisdiction to set aside an arbitral award for error of law on its face was all too capable of being exploited to defeat the intentions of the parties in submitting to arbitration. It was all too easy to convert into an arguable point of law some statement by the arbitrators that in truth amounted to no more than their appreciation of the realities of 
a situation. The line between law and fact can be notoriously difficult to draw. A generous interpretation of what amounts to error of law may be appropriate in tax cases or administrative law cases where the exercise of powers by public authorities against citizens is under review. The same approach is much less satisfactory when used to subvert party autonomy in consensual arbitrations.

The second of the three cases was in the Judicial Committee of the Privy Council in London in 1984. I was sitting as a member of a board of the Judicial Committee chaired by Lord Diplock. The other members were Lord Fraser of Tullybelton, Lord Roskill and Lord Brightman. Not then being a peer, I was the junior member, although one of the others had been appointed a Privy Counsellor more recently than myself. There are rules or conventions in the United Kingdom system of precedence known only to an initiated few. That did not prevent Lord Diplock from inviting me to write the judgment of their Lordships' board. The reason for this gracious invitation was perhaps not far to seek. In part the case turned on some observations which Lord Diplock himself had made the year before in the House of Lords in Sudbrook Trading Estate Ltd $v$ Eggleton. ${ }^{5}$ From the interchange between bench and bar he now drew the inference that I both understood those observations and agreed with them. The first limb of his inference may have been correct. The second was correct up to a point.

This case of 1984 was one of the last of the appeals to the Privy Council from Australia, or at least towards the end of the days of Australian appeals. Possibly more money turned on it than has been at stake in any other case in which I have sat in any jurisdiction. It is Queensland Electricity Generating Board v New Hope Collieries. ${ }^{6}$ It related to a 15-year contract for the supply of coal to the generating board. The contract was made in 1978 and envisaged three five-year periods. For the first period there was an agreed scale of prices, but subject to highly elaborate escalation or price variation provisions enabling adjustment for increased costs falling on the colliery company. For the succeeding periods new price structures were to be negotiated. At any time the price variation provisions themselves were open to review in certain circumstances upon request of either party. There was an arbitration clause in comprehensive but very general terms. During the first five years the company requested a review going back to the very inception of the contract, and also a

5 [1983] 1 AC 444. Lord Diplock, at 479, had contemplated the possibility of a contract upon the true construction of which "the price to be paid is not to be a fair and reasonable one assessed by applying objective standards used by valuers in the exercise of their professional task but a price fixed by a named individual applying such subjective standards as he personally thinks fit".

6 [1989] 1 Lloyd's Rep 205. The case was reported belatedly in England (as distinct from Australia) I think after attention had been drawn to it by the late Francis Mann in his book on The Law of Money. No doubt the editors of the other series of reports thought that it did not merit attention because of its authorship, or that it seemed to state the law too simply to be of any significance. 
review applying to the next five years. The generating board instituted court proceedings in which the issue became whether the arbitration agreement extended to these requests. Two main issues emerged: (i) whether, as to the first five years, arbitration could increase prices retrospectively; and (ii) whether arbitration could establish a new price structure for the ensuing period.

On the first issue the Privy Council held, reversing the courts in Queensland, that arbitration could not extend to varying prices before the date of a request for review. It was accepted that it would have been competent for the parties, in the exercise of their ordinary freedom of contract, to agree specifically on a retrospective price change or an arbitration clause having that drastic scope. But such an unusual degree of retrospectivity could only be authorised by wording of appropriate clarity; and none was to be found. The date of the request for review was held to mark the limit of the retrospective power. Although party autonomy, given a sufficiently clear intention, was thereby recognised, the first was the less important of the two issues.

The second, and more important, issue resulted from a contention for the generating board that the agreement was void for uncertainty as to the periods after the first five years - a mere agreement to agree. Here the Privy Council upheld the conclusion reached in the courts below, albeit on reasoning perhaps not quite the same. Citing Sudbrook and a range of cases from elsewhere in the Commonwealth, the Privy Council said that at the present day, in cases where the parties have agreed on an arbitration or valuation clause in wide enough terms, the courts attach full weight to their manifest intention to create continuing legal relations. Arguments involving alleged uncertainty, or alleged inadequacy of the machinery available to the courts for making contractual rights effective, exert minimal attraction.

The Privy Council reasoning went on that here, by their agreement, the parties undertook implied primary obligations to make reasonable endeavours to agree on the terms of supply and, failing agreement, to do everything reasonably necessary to procure the appointment of an arbitrator. Further, it is implicit in a commercial agreement of this kind that the terms of the new price structure are to be fair and reasonable between the parties. That is the criterion by which the arbitrator is to be guided. If there are cases where the true meaning of the contract is that the arbitrator is to aim, not at objectively fair and reasonable terms, but merely at some result which appeals to him subjectively, they must be rare indeed and the present was certainly not one of them. (The last sentence was something of a qualification of what had been said in Sudbrook.) How the system had worked during the first five years would be likely to provide the arbitrator with much help in determining what was fair and reasonable for the next period. 
Since that case I have remained of the persuasion that, apart from public policy limitations, there is very little that cannot be achieved by arbitration. It is a remedy of almost supreme versatility. A fortiori, conciliation and mediation must share this capacity.

During my presidency of the New Zealand Court of Appeal we had a case which is the very epitome of international commercial arbitration, CBI NZ Ltd v Badger Chiyoda in 1988. It related to extensions to an oil refinery in New Zealand. Badger was a joint venture between a Netherlands and a Japanese company and was the head contractor. CBI, Chicago-controlled, was a subcontractor for the supply and erection of tanks. The subcontract, negotiated at The Hague, provided for arbitration under ICC (International Chamber of Commerce) rules. Disputes arose between the parties, mainly reflecting labour troubles and increased costs incurred by CBI, and they were duly referred to the arbitration of a retired New Zealand High Court Judge. The arbitration took place in New Zealand but, as customary under the rules, was "supervised" by an ICC counsel in Paris. Nevertheless the proper law of the contract was New Zealand law, by express agreement. The parties requested the arbitrator to deliver a partial or interim award ruling on the interpretation of certain clauses in the subcontract and on whether post-contract dealings were admissible as an aid to interpretation. He did deliver such an award. CBI, invoking the inherent common law jurisdiction, applied to the court for the setting aside or remission of the award on the ground of alleged error of law on its face. Badger contended that the jurisdiction was excluded by a clause in the ICC rules providing inter alia that the parties were to be deemed to have waived their right to any form of appeal insofar as such waiver could validly be made.

There was no difficulty in concluding that, though nominally a form of review, the jurisdiction to set aside an award for error of law on the face gives in substance a right of appeal and so was prima facie excluded by the waiver clause. The real issue was whether, as contended by CBI in reliance on Czarnikow $v$ Roth, Schmidt $\mathcal{E} \mathrm{Co}^{8}$ and the traditional attitude of English courts to ouster clauses, the waiver was void as contrary to public policy. Did modern New Zealand public policy require a decision to that effect? A court of five judges unanimously answered the question in the negative.

The view taken was that, while prior decisions based on public policy are not lightly to be abandoned, they are not sacrosanct. Public policy is not static. Changes in society or in attitudes prevailing internationally may show that apprehensions once seen as real and weighty are obviously no longer so. It was well known that for a decade and more there had been a strong trend in common law countries towards giving greater rein to party

7 Above $\mathrm{n} 3$.

8 Above $\mathrm{n} 3$. 
autonomy, partly in emulation of other systems of law and especially in international commercial arbitrations. Contributing causes had been the perceived preferences of businessmen, the clogging of court lists, and in England a phase of heavy resort to the case stated procedure.

It was noted that Czarnikow itself, being concerned with the statutory case stated jurisdiction, did not deal with the old common law review jurisdiction regarding error of law. To apply the Czarnikow approach so as to hold that public policy ruled out attempts to exclude the jurisdiction would give rise to some logical difficulty. For at common law it was undoubtedly open to the parties to exclude that jurisdiction perfectly legitimately, by stipulating that reasons should not be given for the award, or if given should not be treated as part of the award, or by referring a specific question of law to the arbitrator (even a layman).

Far from undermining public policy, the parties to a commercial dispute could be seen to be furthering the public interest by selecting and meeting the cost of their own disputeresolution machinery, rather than resorting to facilities provided and subsidised by the state. Certainly the arbitration might well not provide a publicly-accessible contribution to jurisprudence; but there was no reason why parties freely contracting should be obliged by public policy to make a compulsory contribution to the worthy cause of the coherent evolution of commercial law.

The point about freedom of contract was important. In the instant case the parties who had accepted the waiver clause as part of their contract for arbitration were two very large international concerns. There was no suggestion of inequality of bargaining power. The possibility was left open by the Court of Appeal that where there is manifest inequality of bargaining power or exploitation of a monopoly trade position or the like, so that one party is virtually forced to submit to an ouster clause, there might still be room for the Czarnikow approach. In other words, public policy may require reasonable fairness to individuals. It seems doubtful, however, in India whether the Indian Act is consistent with such an escape route.

The philosophy reinforced for me by the CBI NZ Ltd case is summed up by the proposition that modern public policy points strongly towards non-interference with arbitral decisions if the parties clearly intended them to be final. In all such cases noninterference should be the prima facie rule, with the onus falling on the party who seeks to displace it to show cogent reasons for doing so. That at least seems wholly in accord with the spirit of the Indian Act.

\section{ALLEGED EXCEPTIONS}

In India the main bastions of party autonomy are to be found in sections 7 and 28 of the Arbitration and Conciliation Act 1996. For international commercial arbitrations they 
virtually reproduce provisions of the UNCITRAL model law. The first subsection of section 7 provides:

(1) In this part "arbitration agreement" means an agreement by the parties to submit to arbitration all or certain disputes which have arisen or which may arise between them in respect of a defined legal relationship, whether contractual or not.

Section 28 reads:

Rules applicable to substance of dispute:

(1) Where the place of arbitration is situate in India-

(a) In an arbitration other than an international commercial arbitration, the arbitral tribunal shall decide the dispute submitted to arbitration in accordance with the substantive law for the time being in force in India;

(b) in international commercial arbitration-

(i) the arbitral tribunal shall decide the dispute in accordance with the rules of law designated by the parties as applicable to the substance of the dispute;

(ii) any designation by the parties of the law or legal system of a given country shall be construed, unless otherwise expressed, as directly referring to the substantive law of that country and not to its conflict of laws rules;

(iii) failing any designation of the law under sub-clause (ii) by the parties, the arbitral tribunal shall apply the rules of law it considers to be appropriate given all the circumstances surrounding the dispute.

(2) The arbitral tribunal shall decide ex aequo et bono or as amiable compositeur only if the parties have expressly authorized it to do so.

(3) In all cases, the arbitral tribunal shall decide in accordance with the terms of the contract and shall take into account the usages of the trade applicable to the transaction.

It will be seen that what may conveniently be called ordinary domestic arbitrations are to be decided in accordance with the substantive law of India. There is a refinement regarding the state of Jammu and Kashmir which has its own similar legislation - see the proviso to section 1(2) - but that may be disregarded for present purposes. As to international commercial arbitrations taking place in India, however, the parties are given much more flexibility. Such arbitrations outside India are likely commonly to have as their proper law the law of the place of arbitration, this representing a change from the position 
previously established by Supreme Court decisions, ${ }^{9}$ but again the present paper is not concerned directly with that category of cases. Its direct concern is the important category of international arbitrations where the place of arbitration chosen by the parties, in pursuance of their freedom of choice under section 28(1), is India; or where, failing such an agreement by the parties, the arbitral tribunal designates India in exercise of the power conferred by section 28(2). "International commercial arbitration" is defined by section 2(f) in terms which are quite elaborate and need not be reproduced. Broadly, they stipulate that at least one of the parties is based outside India.

A question which therefore calls for examination is whether in international commercial arbitrations taking place in India the Act denies the parties freedom of choice of the governing principles to an extent constituting a significant inroad into the concept of party autonomy. The relevance of the question arises from the emergence during the second half of the twentieth century, particularly from the nineteen-sixties onwards, of "the new lex mercatoria" and such compilations as the UNIDROIT Principles of International Commercial Contracts ${ }^{10}$ and Principles of European Contract Law, Part I. ${ }^{11}$ Can principles derived from such sources form the basis of international commercial arbitrations held in India under the Act of 1996? If any doubt is still entertained in India on this point by ICADR or members of the legal or other professions, I hope that it may soon be put to rest. It would savour of an age now past.

The passing of the age may be identified in England with Home Insurance Co Ltd $v$ Mentor Insurance Co (UK) Ltd in 1988. ${ }^{12}$ In that case Hirst J in the High Court had granted a stay of certain court proceedings in the light of an arbitration clause providing:

The Arbitrators and the Umpire shall interpret this Reinsurance as an honourable engagement and they shall make their award with a view to effecting the general purpose of this Reinsurance in a reasonable manner rather than in accordance with a literal interpretation of the language.

The Court of Appeal unanimously affirmed the stay, but, contrasting positions were taken in the two reasoned judgments then delivered. ${ }^{13}$ Parker LJ said: ${ }^{14}$

9 NTPC v Singer Company [1992] 3 SCC 551; Sumitomo Heavy Industries Ltd v DNGC Ltd [1998] 1 SCC 305.

10 Rome, 1994.

11 First Commission on European Contract Law, 1995.

12 [1989] 3 All ER 74.

13 Home Insurance above n 12, 85. The third member of the court, Balcombe LJ, said that he agreed with both judgments. 
I have no hesitation in accepting the submission of counsel for Home that a clause which purported to free arbitrators to decide without regard to the law and accordingly, for example, to their own notions of what would be fair would not be a valid arbitration clause.

He doubted, however, whether the clause did any more than authorise the arbitrators to apply an approach to interpretation founded on business efficacy rather than a literal or ordinary one. That was, with respect, the voice of the past. Lloyd LJ in this matter may be thought to have spoken for the future when he said, after citing DST $v$ Raknoc (to which I will refer in a moment) and other authorities: ${ }^{15}$

Counsel for Home argued that DST $v$ Raknoc was concerned only with the enforcement of a foreign award, and that it has no bearing on the present case, where the contract calls for arbitration in London. But why not? If the English courts will enforce a foreign award where the contract is governed by a "system of "law" which is not that of England or any other state or is a serious modification of such a law" (see [1987] 2 All ER 769 at 778, [1987] 3 WLR 1023 at 1034), why should it not enforce an English award in like circumstances? And if it will enforce an English award, why should it not grant a stay?

Counsel for Home argued that it would be impossible for the court to supervise an arbitration unless it is conducted in accordance with a fixed and recognisable system of law; he even went so far as to submit that the arbitration clause in the present case is not an arbitration agreement within the meaning of the Arbitration Acts 1950 to 1979. It is sufficient to say that I disagree. I would only add (although it cannot affect the argument) that if counsel for Home is right, no ICC arbitration could be held with confidence in this country for fear that the arbitrators might adopt the same governing law as they did in DST $v$ Raknoc.

DST $v$ Raknoc, ${ }^{16}$ otherwise known as the Ras al Kaimal or Rakoil case, related to an award by arbitrators in Geneva arising from an oil and gas exploration contract which the government of a Gulf state and its oil company had repudiated for alleged misrepresentation. The award was in favour of the other party, a foreign consortium. The arbitrators held that the proper law of the contract was simply internationally accepted principles of contract law. Enforcement being resisted on the ground that English law would not recognise an award based on such principles, Sir John Donaldson MR said that by choosing to arbitrate under ICC rules the parties had left the proper law to be decided by the arbitrators and had not in terms confined the choice to national systems of law. He could see no basis for concluding that the arbitrators' choice of proper law - a common

14 Home Insurance above n 12, 80.

15 Home Insurance above n 12, 84-85.

16 [1990] 1 AC 295, 316. The case went to the House of Lords on another point not requiring consideration of the opinion of the Master of the Rolls for which I am citing it. 
denominator of principles underlying the law of the various nations governing contractual relations - was outwith the scope of the choice which the parties left to the arbitrators.

Since the Home Insurance case the most significant relevant judicial decision in England has probably been Channel Tunnel Group v Balfour Beatty Ltd. ${ }^{17}$ The House of Lords upheld a stay of court proceedings where the contract providing for reference to experts and subsequent arbitration was expressed to be governed by those principles of English and French contract law which are common and, in the absence of any such common principles, by such general principles of international trade law as have been applied by national and international tribunals. Throughout the history of the case no one appears to have sought to ventilate any issue as to the efficacy of this choice-of-law clause. It is of much interest, for reasons which I am about to mention, that the leading speech in the House of Lords was delivered by Lord Mustill.

The lex mercatoria of our age has emerged largely from arbitration clauses in or incorporated in international commercial contracts, expressed in terms sufficiently wide to require or allow arbitrators, in determining a dispute on the merits, to apply criteria transcending the law of any particular country. ${ }^{18}$ Typically they concern an actual or apprehended dispute between a contractor, concessionaire or lender based in a developed capitalist society, on the one hand, and developing states or their agencies, on the other, arising out of natural resources exploitation or development loans. The concept of the lex mercatoria thus owes much to fear of alteration of local laws, by nationalisation or less extreme steps, to the disadvantage of the overseas party. International development banks quite commonly have lex mercatoria conditions or the like as part of their standard terms of lending. But, as the Channel Tunnel Group case demonstrates, in international commercial dealings between parties of comparable standing and bargaining power the concept also has a natural attraction.

With the ever-increasing internationalisation of commerce it seems almost inevitable that the lex mercatoria will increasingly flourish. Yet it has had, and no doubt still has, powerful critics. The late Francis Mann was one. The most influential living critic is probably Lord Mustill, now retired as a Law Lord and returned to a leading role in the fold of professional arbitrators. In his contribution to Liber Amicorum for Lord Wilberforce in

17 [1993] AC 334.

18 Some of the present paper is an adaptation of part of my (unpublished) lecture, entitled The Common Law of the World, for the British Institute of International and Comparative Law, given in the India Office Council Chamber at the Foreign and Commonwealth Office, London, on 2 December 1997. It has been revised, however, and is presented mainly from the point of one speaking in New Delhi rather than King Charles Street. For New Zealand readers an addendum at the end speaks as from a window overlooking Lambton Quay. 
1987, entitled The New Lex Mercatoria, The First Twenty-Five Years, Sir Michael Mustill, as he then was, made it clear that his friendship did not extend to the doctrine on which he wrote. It is a sustained, skilfully-argued analytical assault on the lex, based on grounds such as vagueness and absence of identifiable ancestry. He gave a list of twenty propositions as representing "a tolerable complete account of the rules which are said to constitute the lex mercatoria in its present form". These he described as "a comparatively modest haul for twenty-five years of international arbitration". When his paper was republished a year later, ${ }^{19}$ he found it necessary to point out specifically that he was not suggesting that the twenty claims could be sustained in all cases, "at least if the lex is given its "macro" connotation". ${ }^{20}$ Evidently some supporters of the lex mercatoria, far from seeing the haul as modest, had held up the list compiled by such an eminent author as compelling evidence of its triumph. As might be expected, the leading English textbook Mustill and Boyd in The Law and Practice of Commercial Arbitration ${ }^{21}$ treats the subject on lines similar to those of the paper.

A more florid treatment of the subject, albeit reflecting a similar point of view, is by a writer in the Tulane Law Review in 1989:22

The lex mercatoria obviously does exist, to the extent that scholars and practitioners talk about it and identify it. It is, however, a scholarly fantasy to assert that something exists just because one can talk about it in the course of questioning its existence. It may, like the Emperor's clothes, be non-existent, and yet one can still argue about it at great length. To dispute the existence of something cannot itself have any effect on the outcome of that inquiry. Otherwise, all one would have to do to verify the existence of a principle would be to deny it. It is more useful to discuss the extent to which the lex mercatoria possesses validity or vitality, and the extent to which it is what it pretends to be or - more accurately - what some would have it be. The lex mercatoria is in fact an enigma, created by a paradox that placed many investors in a dilemma. The paradox has in turn created a quandary from which the only way out was to arrive at the enigma by way of a fallacy.

A less condemnatory, if not exactly enthusiastic, position is taken by Professor Roy Goode $^{23}$ in an article published in 1997. ${ }^{24}$ With a scholar's vocational predilection for

19 (1988) 4 Arbitration International.

20 Above n 19, 110, n 81a.

21 (2 ed, Butterworths, London, 1989) 74-86.

22 Keith Highet "The Enigma of the Lex Mercatoria" (1989) 63 Tulane L Rev 613, 616.

23 Aptly described on the dust cover of Ross Cranston (ed) Making Commercial Law (Clarendon Press, Oxford, 1997) as "one of the century's outstanding commercial law scholars".

24 "Usage and its Reception in Transnational Commercial Law" (1997) 46 ICLQ 1, 35-6. 
expoundable rules, it is not surprising that he sees the diversity of approaches in arbitration as tending to undermine the unifying effects of an international law merchant; and he does not consider it the function of arbitral awards to develop international jurisprudence. All that matters at the end of the day, he says, is that the arbitral tribunal reaches a result that commends itself to the reasonable man as just in the particular case. I dare to interpolate that this is a great deal of what matters in the decisions of any court under any system of law; systems of law are successful to the extent that they result in the just decisions of particular cases. Professor Goode's cautious conclusion is "so perhaps the growing recourse to international trade usage, to the exclusion of national law, is not a bad thing after all".

Despite its critics, and despite the instinctive reaction of many lawyers when having occasion to wrestle with the idea for the first time, support for the lex mercatoria and even wider general principles appears to be growing steadily among writers and those professionally involved in arbitrations. To compile a bibliography of the literature in this field is not a task for which I am volunteering. It will have to be enough to mention a few contributions that I respectfully recommend as positive and helpful, and to give some hint of their flavour.

My list begins with a paper by Stewart Boyd QC published in 1990 on "Arbitrators not to be bound by the Law" Clauses. ${ }^{25}$ The second joint author of Mustill and Boyd appears to take a view rather different from the first, for he sees " no possible injury to the administration of justice in England or to the purity and clarity of English commercial law which would flow from giving such clauses [viz, equity and good conscience clauses, which he treats as embracing or falling under the same head as the lex mercatoria] their full meaning and effect". In the same journal there follows Lex Mercatoria: An Arbitrator's View ${ }^{26}$ by Professor Andreas F Lowenfeld of the New York University School of Law. He concludes, speaking from much practical experience, that most arbitrators do not look first of all for compromise. "International arbitrators do seek to achieve just results within a legal framework, and that framework is by definition wider than the frontiers of any state. To me, this is the vision, the promise, and the usefulness of lex mercatoria".

An important contribution from a member of the New York bar is David W Rivkin's Enforceability of Arbitral Awards Based on Lex Mercatoria in 1993. ${ }^{27}$ This article gives many actual examples of arbitrations conducted on that or a like basis in a variety of jurisdictions. He cites authority leading him to perceive a likelihood that United States

25 "Arbitrators not to be bound by the Law Clauses" (1990) 6 Arbitration International 122, 130.

26 (1990) 6 Arbitration International 133.

27 "Enforceability of Arbitral Awards Based on Lex Mercatoria" (1993) 9 Arbitration International 67. 
courts will respect the parties' choice of a non-national standard to govern the merits of their dispute.

There is a valuable synthesis by Jérôme Huet in The Unidroit Principles for International Commercial Contracts: A New Lex Mercatoria published in $1995 .{ }^{28}$ In the following year an informative article about international development loans was published in the United States. $^{29}$ And the 1997 compilation in honour of Roy Goode which I have noted previously ${ }^{30}$ contains a number of instructive pieces, among which I specify, if invidiously, Professor Ole Lando's Eight Principles of European Contract Law, ${ }^{31}$ since it comes from one of the most noted proponents of the lex, and Professor M J Bonell's piece with a long title ${ }^{32}$ but being essentially a comparison of contract law principles. The last-mentioned paper includes a striking example of a recent arbitration between an English company and an Iranian government agency in which the governing substantive law had been agreed to be simply "principles of natural justice". ${ }^{33}$ The arbitral tribunal decided, I understand by a majority of two to one (an eminent English Queen's Counsel dissenting), that these principles are wide enough to import a duty to bring and prosecute a claim without unreasonable delay, although there was found in that case to be no breach of the duty.

The onward march of the concept of principles transcending national boundaries is marked further by section 46 of the Arbitration Act 1996 extending to England and Wales and (with exceptions) Northern Ireland. Again these provisions are UNCITRAL inspired:

46. Rules applicable to substance of dispute

(1) The arbitral tribunal shall decide the dispute-

(a) in accordance with the law chosen by the parties as applicable to the substance of the dispute, or

(b) if the parties so agree, in accordance with such other considerations as are agreed by them or determined by the tribunal.

(2) For this purpose the choice of the laws of a county shall be understood to refer to the substantive laws of that country and not its conflict of laws rules.

28 Institute of International Law and Practice, 279.

29 John Head "Evolution of the Governing Law for Loan Agreements of the World Bank and other Multi-lateral Development Banks" (1996) 90 American Journal of International Law 214.

30 Above $\mathrm{n} 23$.

31 Above n 23, 103.

32 Above n 23, 91.

33 Above n 23, 100. 
(3) If or to the extent that there is no such choice or agreement, the tribunal shall apply the law determined by the conflict of laws rules which it considers applicable.

Of this Lord Justice Saville's Committee said in their report of February 1996: ${ }^{34}$

223. Sub-section (1) (b) recognizes that the parties may agree that their dispute is not to be decided in accordance with a recognized system of law but under what in this country are often called "equity clauses", or arbitration "ex aequo et bono", or "amiable composition" ie general considerations of justice and fairness etc.. It will be noted that we have avoided using this description in the Bill, just as we have avoided using the Latin and French expressions found in the Model Law. There appears to be no good reason to prevent parties from agreeing to equity clauses. However, it is to be noted that in agreeing that a dispute shall be resolved in this way, the parties are in effect excluding any right to appeal to the Court (there being no "question of law" to appeal).

If "law" be regarded as including generally-recognised principles, subsection (1)(b) also covers the ground to which the committee refer. As to exclusion of any right of appeal to the court, so far as the section achieves this it accords with the principle of party autonomy.

\section{THE MEANING OF SECTION 28 OF THE INDIAN ACT}

While the true meaning of section 28 is of course governed by its own wording read in the context the Act of 1996 as a whole, the international developments just sketched are an aid to interpretation. They help us to see the section in perspective and with an awareness of the issues with which the section was designed to deal.

For our purposes the first point to be noted about the section is that subsection (2) disposes of the once prevailing but now outdated approach illustrated by the judgment of Parker LJ in the Home Insurance case. In this subsection it is implicit that an international commercial arbitration, to take place in India, may be validly constituted under the Indian Act notwithstanding that the parties have left the arbitrators an extremely wide freedom to depart from the rules of any legal system. If the parties have done so, the award will be final under section 35 , subject to the quite stringently restricted grounds for setting aside specified in section 34 .

The subsection is capable, however, of giving rise to some difficulties of interpretation. To bring their agreement within it, the parties must expressly authorise the arbitral tribunal to decide ex aequo et bono or as amiable compositeur. How express is express? Presumably it is unnecessary to use the precise Latin or French phrases. Equivalent terminology in English or any other language should do. According to the glossary in Russell on

34 Above $\mathrm{n} 1$. 
Arbitration, ${ }^{35}$ the two phrases would appear to mean the same thing. That standard work defines Amiable Compositeurs as "arbitrators who resolve disputes without recourse to strict application of any particular law". But the qualification "strict", suggestive as it is of only a limited flexibility, rather muddies that definition. Moreover, to many people the French words are more suggestive of conciliation or mediation than of arbitration.

Whatever the position under section 28(2), I am disposed to think that section 28(1)(b) provides all the party autonomy that is needed. There are some fine, but potentially important, differences in the terms of its three paragraphs. Paragraph (i) has "the rules of law"; paragraph (ii) has "the law or legal system of a given country"; paragraph (iii) returns to "the rules of law". It seems a fairly plain inference that, whereas paragraph (ii) applies only where the parties have designated a given national system, and is intended to make it clear that this refers to the substantive law of that system rather than its conflict of laws rules, paragraphs (i) and (iii) are not restricted to particular national systems. That is to say, those paragraphs leave the parties or the arbitrators, as the case may be, free to select any governing principles which can fairly be described as rules of law. UNIDROIT principles, for instance, are not the law of any given country; but they have been deliberately promulgated as rules of law which are intended to be available internationally for choice in the exercise of party autonomy.

The foregoing approach can be taken further. It can be applied to more generallyexpressed choices, such as principles common to legal systems, or the rules of natural justice, or even simply fair and reasonable. Here I venture to go back to the Queensland Electricity case ${ }^{36}$ and the qualification there added by the Privy Council to Lord Diplock's exposition in the Sudbrook case. ${ }^{37}$ It is fallacious to equate mere personal predilection, whim or caprice with a decision as to what is fair and reasonable. Parties who agree on the latter standard formula do not intend their tribunal to decide arbitrarily or irrationally. They have in mind, rather, the everyday objective standard of the reasonable man. It is a standard constantly applied in other main fields of law.

The reasonable man is forever appearing in the law of negligence, tort, contract, trust, crime, and so on. Certainly it is a standard that often allows for choice. Indeed the need for principles of some flexibility capable of achieving justice in a great range of particular cases is its very raison d'etre. But, wherever the standard applies, the postulate is always that it is an objective one, entailing a search for what a hypothetical person of common

35 Russell on Arbitration (21 ed, Sweet and Maxwell, London, 1997) 456.

36 Above $\mathrm{n} 6$.

37 Above $n$. 
sense (or a reasonable skilled person holding himself or herself out as having vocational skill) would do in the circumstances of the case.

The argument commonly applied against resort to the simple standard of reasonableness is uncertainty. It is exactly the same principal argument as is advanced by the critics of the lex mercatoria. But it is not allowed to prevail in other branches of the law. Furthermore, it tends to exaggerate the extent to which a system of ostensibly more blackand-white rules truly does produce certainty. The law reports are full of cases where these rules fall short or are unclear or clash or merge into grey areas. Even as reputedly sophisticated and certain a subject as the English common law of contract is a minefield of uncertainties. $^{38}$

For these reasons I submit that the Indian Act of 1996 gives parties to international commercial arbitrations full ability, in the exercise of their autonomy, to have their disputes arbitrated in accordance with broad common principles of justice crossing national boundaries. So far as is consistent with any agreement of the parties, arbitrators should enjoy the like power. It is true that arbitrations based on such principles do not contribute much detailed law to the textbooks. Nevertheless the materials cited earlier in this paper indicate that, with the help of codifications offered by teams of scholars, viable general principles are being gradually but fruitfully evolved in the commercial field. It is all part of the evolution of a common law of the world, which in the very long term can be seen as an achievable goal of mankind.

\section{INDIAN CASE LAW BEFORE THE ACT OF 1996}

Upon request the ICADR has kindly supplied me with some references to decisions under the former law of India. These are outside the scope of the present paper and chiefly of historical interest, although the old law continues to apply to awards made under the former legislation. Under the Indian Arbitration Act 1940 the Supreme Court accepted that, provided that an error of law appeared on the face of an award and that the case was not one of the reference to an arbitrator of a specific question of law, the arbitrator was not a conciliator and could not ignore the law in order to do what he thought just and reasonable. So the court could set aside the award: Thawardas $v$ Union of India, ${ }^{39}$ Continental Construction Co Ltd $v$ State of Madhga Pradesh. ${ }^{40}$ It is to be noted that these were evidently domestic arbitrations, not international commercial arbitrations, and that the arbitration agreements contained no equity clauses. Where the Act of 1996 applies, arbitral decisions

38 See a review of Consensus ad Idem, Essays in the Law of Contract in Honour of Geunter Treitel, edited by Francis Rose (1998) 114 LQR 505.

39 (1955) 2 SCR 48.

40 (1988) 3 SCC 82 
in cases within this category will apparently be invulnerable, notwithstanding alleged error of law on the face of the award, unless some ground of a jurisdictional nature can be established - which could be difficult.

By contrast there is a judgment of the Judicial Committee of the Privy Council, Sitanna $v$ Viranna ${ }^{41}$ relating to a family inheritance dispute, where after a very belated challenge (no less than 41 years had elapsed) an award of a panchayat was left standing on the following broad grounds, as stated by Sir John Wallis: ${ }^{42}$

Reference to a village panchayat is the time-honoured method of deciding disputes of this kind, and has these advantages, that it is generally comparatively easy for the panchayatdars to ascertain the true facts, and that, as in this case, it avoids protracted litigation which, as observed by one of the witnesses, might have proved ruinous to the estate. Looking at the evidence as a whole their Lordships see no reason for doubting that the award was a fair and honest settlement of a doubtful claim based both on legal and moral grounds, and are therefore of opinion that there are no grounds for interfering with it.

Thus, 60 years and more before the Act of 1996, the Privy Council anticipated a good deal of its spirit.

\section{THE NEW ZEALAND ACT OF 1996}

In New Zealand the Arbitration Act $1996^{43}$ largely following recommendations of the Law Commission, was enacted on 2 September 1996, in the same year as the English and Indian Acts and in the same mould inasmuch as it is strongly influenced by UNCITRAL and is permeated by the principle of party autonomy. But the New Zealand Act is very different in structure and considerably different in substance. The main body of the Act is in appearance fairly simple, consisting of a mere twenty sections. Then, annexed in five Schedules, are Rules Applying to Arbitration Generally: Additional Optional Rules Applying to Arbitration: Treaties Relating to Arbitration: Enactments Amended: and Enactments Repealed. The advantage of this structure is a certain tidiness and elegance, the disadvantage that arriving at a conclusion as to the effect of the Act in any given case can be like orienteering.

\section{AIR PC 105}

42 Above $\mathrm{n} 41,107$.

43 For a fuller account of the Act, see Arbitration and Dispute Resolution by D A R Williams Q C in [1998] NZ Law Rev 1. The New Zealand Law Society's seminar paper (May 1997) on the Act by Fred Thorp and David Williams Q C is also useful. The Law Commission Report is Arbitration (Report 20 NZLC, 1991). 
The most distinctive feature of substance in the New Zealand Act is that, for arbitrations in New Zealand, section 6 lays down an original approach to the difference between international arbitrations (as defined) and all others. The Act does not speak of domestic arbitrations, but that term may be used for convenience. In domestic arbitrations some most important rules apply unless the parties agree otherwise. By Article 5 of the Second Schedule, these include a right of appeal to the High Court, with the leave of that court, on any question of law arising out of an award; with a further appeal to the Court of Appeal by leave. In sharp contrast, such appeals are only available in international arbitrations if the parties so agree. In all arbitrations, however, the High Court (presumably subject to appeal) has power under article 34 of the First Schedule to set aside an award on such grounds as invalidity of the arbitration agreement, excess of the scope of the submission, fraud or breach of natural justice.

There are in section 11 of the New Zealand Act special provisions regarding consumer agreements (quite widely defined) aimed at ensuring that consumers do not accept arbitration unless they have unequivocally agreed to it in writing. ${ }^{44}$

As for the rules applicable to the substance of the dispute, the First Schedule of the New Zealand Act provides:

\section{$28 \quad$ Rules applicable to substance of dispute}

(1) The arbitral tribunal shall decide the dispute in accordance with such rules of law as are chosen by the parties as applicable to the substance of the dispute. Any designation of the law or legal system of a given state shall be construed, unless otherwise expressed, as directly referring to the substantive law of that State and not to its conflict of laws rules.

(2) Failing any designation by the parties, the arbitral tribunal shall apply the law determined by the conflict of laws rules which it considers applicable.

(3) The arbitral tribunal shall decide ex aequo et bono or as amiable compositeur (according to considerations of general justice and fairness) only if the parties have expressly authorised it to do so.

44 It may be as well to note here that the English Act of 1996, s 87, provides that a clause in a domestic agreement excluding appeals to the court on questions of law is not effective unless entered into after the commencement of the arbitral proceedings. This section has not been brought into force, however, as it was thought to be contrary to the Treaty of Rome in putting United Kingdom consumers at an advantage over consumers elsewhere in the European Community. Sections 89 to 91 of the English Act make applicable to consumer arbitration agreements certain regulations relating to unfair terms. These complications are among the quite numerous differences between current New Zealand and current English arbitration law. 
(4) In all cases, the arbitral tribunal shall decide in accordance with the terms of any contract and shall take into account any usages of the trade applicable to the transaction.

This is almost identical with article 28 of the UNCITRAL Model Law, although the New Zealand version adventurously and generously explains ex aequo et bono or as amiable compositeur as meaning "according to considerations of general justice and fairness".

Notice that the New Zealand article 28 applies to all arbitrations. Unlike India, New Zealand does not insist on domestic arbitrations being determined in accordance with domestic law. In this respect New Zealand is more thoroughgoing in accepting party autonomy. To the extent that the parties are free to select the rules of law applicable to the substance of their dispute, the Indian and New Zealand statutory provisions are the same, except for the New Zealand explanatory definition just mentioned. So my suggestion that the parties need not designate any specific national system but may, for instance, select the lex mercatoria can also be made regarding the New Zealand Act. The lex mercatoria is, after all, comprised of rules, even though their content is still evolving and they are somewhat general. Nonetheless, it may be safely predicted that for some time to come the lex mercatoria, the UNIDROIT principles and the like will rarely be applied as such in New Zealand unless the parties have expressly authorised the arbitral tribunal to decide on that basis, pursuant to their liberty under article 28(1) or article 28(3).

A strict constructionist, if there are any left, could wreak mischief by reading article 28(3) as prohibiting the arbitral tribunal from deciding according to considerations of general justice and fairness in all cases where the parties have not given express authority, even if those considerations happened to produce the same result as that of an applicable state system. I hazard the guess that this risk need not be taken seriously, although the possibility cannot be excluded that some desperate counsel might not be above trying some version of the idea.

What is to be taken seriously is that the New Zealand legislation goes a very long way, further than England, further than India, in the direction of party autonomy. It will be illuminating to see how often, in domestic arbitrations, the parties exercise their power to contract out of appeals to the court by leave on questions of law. This is partly an issue of confidence in the judicial system on the one hand and the qualities of arbitrators on the other. On it I am not prepared to hazard any guess. 
